\title{
Toxic alkaloid levels in tall larkspur (Delphinium barbeyi) in western Colorado
}

\author{
JAMES A. PFISTER, GARY D. MANNERS, DALE R. GARDNER, AND MICHAEL H. RALPHS \\ Pfister and Ralphs are range scientists, and Gardner is research chemist, USDA-ARS Poisonous Plant Reseanch Lab., 1150 \\ E. 1400 N., Logan, UT 84321; Manners is research chemist, USDA-ARS Western Regional Research Lab., Albany, CA 94710.
}

\section{Abstract}

Consumption of tall larkspur (Delphinium barbeyi L. Huth.) can be fatal to cattle grazing mountain rangeland during summer. Tall larkspur contains many alkaloids, but virtually all the toxicity is caused by methyl succidimido anthranoyl lycoctonine-type (MSAL) diterpenoid alkaloids. We measured the concentration of MSAL alkaloids ( $\%$ of dry matter) in tall larkspur in various phenological stages during 1990, 1991, and 1992 near Yampa, Colorado. The site represented tall larkspur-infested rangelands on the western slope of the Rocky Mountains. Toxic alkaloid concentrations were greatest $(0.4$ to $0.6 \%)$ early in the growing season (bud stage). Toxic alkaloid concentrations were generally static during the flower and pod stages, or increased during the pod stage. Immature leaves had greater MSAL alkaloid concentrations early in the growing season compared to flowering parts. Alkaloid concentrations in pods were greater than in leaves ( $P<0.05 ;$ pod stage), as pod concentrations increased to $0.4 \%$ late in the growing season. In 2 of 3 years, plant parts did not differ in MSAL alkaloid concentrations, although weather conditions differed each year. Concentrations of toxic alkaloids did not seem to influence amounts of tall larkspur consumed by grazing cattle on the same sampling dates. Many livestock producers defer grazing of tall larkspur ranges until the plant is in the pod stage because of a general belief that toxicity is greatly reduced. Our results suggest that grazing tall larkspur ranges during the pod stage may exacerbate cattle losses if MSAL alkaloid concentrations do not decrease, yet consumption by cattle increases.

Keywords: diterpenoid alkaloids, methyllycaconitine, poisonous plants, cattle grazing

Tall larkspur (Delphinium barbeyi L. Huth.) toxicity is a serious problem on mountain rangelands during summer (Ralphs et al. 1988). Death losses in cattle from consumption of tall larkspur are often severe and may curtail grazing where the plant is abundant (Nielsen and Ralphs 1988). Losses are especially severe on the western slope of the Colorado Rocky Mountains (e.g., Routt and White River National Forests).

Tall larkspur contains $>15$ diterpenoid alkaloids, but the most toxic compounds of this group are the methyl succidimido anthranoyl lycoctinine-type (MSAL) alkaloids, methyllycaconitine (MLA) and 14deacetylnudicauline (14-DAN; Manners et al. 1992, 1993). Reversal of MSAL alkaloid toxicity is simple and effective using injections of physostigmine (Nation et al. 1982, Pfister et al. 1994b). Nonetheless,

\footnotetext{
We thank Kermit Price and Tracy Weber for assistance with the study. We express appreciation to the personnel of the Yampa Ranger District, especially Connie Clementson, for their cooperative efforts. We also thank Mr. and Mrs. Bob McKune for allowing research activity on their allotment.

Manuscript accepted 2 Apr. 1994.
}

prudent grazing management of tall larkspur-infested rangelands requires knowledge of toxin concentrations over time. There is no information available on toxic alkaloid concentrations in tall larkspur in the western Colorado area; hence, the purpose of our study was to characterize concentrations of MSAL alkaloids in tall larkspur over several growing seasons.

\section{Methods}

The study was conducted during the summers of 1990,1991 , and 1992 on the U.S. Forest Service North Hunt Allotment near Yampa, CO. The study site was a moist, aspen/tall forb type (Mitchell 1993), representative of mountain rangelands dominated by tall larkspur in western Colorado (Mitchell 1993). Cattle grazing was discontinued 3 years before our study because of severe losses from tall larkspur toxicosis. Much of the allotment had a forested overstory that consisted primarily of aspen (Populus tremuloides Michx.) and douglas fir (Pseudotsuga menziesii [Mirbel] Franco). Dominant forb, shrub, and grass species were tall larkspur, false hellebore (Veratrum californicum Durand), cow parsnip (Heracleum lanatum Michx.), meadowrue (Thalictrum fendleri Engelm.), sweet cicely (Osmorhiza occidentalis [Nutt.] Torr.), snowberry (Symphoricarpos oreophilus Gray), and mountain brome (Bromus carinatus Hooker \& Am.).

Tall larkspur was collected on this allotment about $14 \mathrm{~km}$ west of Yampa, Colo. near the Dunckley Pass Road between the Forest Service boundary and Chapman Reservoir at about $2,700 \mathrm{~m}$ elevation. During each collection, leaves and reproductive parts (i.e., bud, flower, pod) were collected from $>20$ individual plants (Table 1), composited, and frozen. Frozen material was freeze-dried and ground to pass a $1-\mathrm{mm}$ screen in a Wiley mill. One-gram samples were extracted and analyzed for MSAL alkaloids by the method of Manners and Pfister (1993) using high-performance liquid chromatography (HPLC). Occurrence of MSAL alkaloids (free-base form) was calculated using colchicine as an internal standard for MLA and 14-DAN. In this paper, total toxic alkaloids is equal to the sum of MLA and 14DAN concentrations.

Diets of 6 to 12 grazing cattle on this allotment were determined each summer using bite counts as described by Pfister and Manners (1991). Yearling heifers (1990, $286 \mathrm{~kg}$; 1992, $295 \mathrm{~kg}$ ) and 2-year old heifers $(1991,372 \mathrm{~kg})$ were used. Briefly, individual animals were observed for sequential, 5-min periods throughout all daylight hours, and bites of tall larkspur, other forbs, grass, and shrubs were recorded. In this paper, we report cattle diets (percentage of bites) on each specific day that tall larkspur samples were collected.

Alkaloid data were tested for normality using the univariate procedure of SAS (1987). The normal probability plot resembled a straight line, indicating only moderate departure from normality. The model included the effects of plant part, plant phenology, years, part $x$ phenology, year $x$ phenology, year $x$ part, and the three-way interaction. The three-way interaction was not significant $(P>0.10)$, and was 
Table 1. Sampling dates and corresponding phenological stages for tall larkspur collected near Yampa, Colorado.

\begin{tabular}{|c|c|c|c|}
\hline 1990 & $\begin{array}{l}\text { Jun. } 9 \\
\text { Jun. } 22 \\
\text { Jul. } 7 \\
\text { Jul. } 19 \\
\text { Aug. } 5\end{array}$ & $\begin{array}{l}\text { vegetative/early bud } \\
\text { bud } \\
\text { early flower } \\
\text { full flower } \\
\text { pod }\end{array}$ & $\begin{array}{l}\text { small buds formed on some racemes } \\
\text { buds formed on racemes; racemes not elongated } \\
\text { most racemes elongated; flowers not opened } \\
\text { racemes elongated; flowers opened fully } \\
\text { pods fully formed; many plants senescing }\end{array}$ \\
\hline 1991 & $\begin{array}{l}\text { Jun. } 26 \\
\text { Jul. } 7 \\
\text { Jul. } 12 \\
\text { Jul. } 19 \\
\text { Jul. } 25 \\
\text { Aug. } 2 \\
\text { Aug. } 9 \\
\text { Aug. } 14\end{array}$ & $\begin{array}{l}\text { bud } \\
\text { early flower } \\
\text { early flower } \\
\text { full flower } \\
\text { full flower } \\
\text { early pod } \\
\text { pod } \\
\text { pod }\end{array}$ & $\begin{array}{l}\text { buds formed on racemes; racemes not elongated } \\
\text { most racemes elongated; flowers not opened } \\
\text { racemes elongated; flowers opened fully } \\
\text { pods incompletely formed } \\
\text { pods fully formed } \\
\text { pods fully formed; some plants senescing }\end{array}$ \\
\hline 1992 & $\begin{array}{l}\text { Jun. } 15 \\
\text { Jul. } 14 \\
\text { Jul. } 17 \\
\text { Jul. } 28 \\
\text { Aug. } 7 \\
\text { Aug. } 11 \\
\text { Aug. } 19 \\
\text { Aug. } 25\end{array}$ & $\begin{array}{l}\text { vegetative/early bud } \\
\text { early flower } \\
\text { early flower } \\
\text { full flower } \\
\text { full flower } \\
\text { late flower/early pod } \\
\text { pod } \\
\text { pod }\end{array}$ & $\begin{array}{l}\text { small buds formed on some racemes } \\
\text { most racemes elongated, flowers not opened } \\
\text { racernes elongated; flowers opened fully } \\
\text { mixed flowers/pods on racemes } \\
\text { most pods fully formed } \\
\text { pods fully formed; some plants senescing }\end{array}$ \\
\hline
\end{tabular}

- Most larkspur plants were in the designated phenological stage when samples were collected. Larkspur phenology depends greatly on summer moisture and ambient temperatures.

- Beginning with lower leaves, larkspur leaves turn yellow as plants senesce.

pooled with the residual error term. When significant interactions were found, the LSD procedure was used to compare individual means. No analyses were done to compare calendar dates among years. Significance was declared at $P<0.05 ; P<0.10$ was interpreted to indicate a trend.

\section{Results and Discussion}

There was a phenology effect, and a year $x$ phenology interaction $(P<0.05$, Fig. 1). Alkaloid concentrations were greater during the bud stage in 1990 and 1991 compared to 1992 (Fig. 1). Further, MSAL alkaloid concentrations were greater during the full flower stage in 1990 compared to 1991. During 1991, alkaloid concentrations were also greater during the pod stage than during the full flower stage. In general, total toxic alkaloid concentrations were greater in immature larkspur than in more mature plants. Majak (1993) reported similar trends in MLA concentrations for vegetative and flowering low larkspur in Canada.

The phenology $x$ plant part interaction was significant $(P<0.05$; Fig. 2). Concentrations of total toxic alkaloids in leaves decreased significantly from bud to early flower stages, but did not decrease thereafter. There was a tendency for bud material to have a greater concentration of toxic alkaloids compared to flower material $(P<0.1)$. Tall larkspur pods had greater concentrations of total toxic alkaloid than did reproductive material collected during early or full flower stages (Fig. 2).

There was a significant year $x$ plant part interaction. During 1991, leaf material had greater alkaloid concentrations than did reproductive material (Fig. 3). There were no differences in alkaloid concentrations in plant parts during other years. The lack of year differences in 2 of 3 years is notable because climatic variation, primarily in temperature and precipitation, could be expected to produce differential concentrations of alkaloids in plant parts (Gershenzon 1984). Generally, 1990 was drier and warmer than normal, while 1992 was wetter and cooler than normal (NOAA 1990, 1991, 1992). Weather influenced tall larkspur maturation on specific calendar dates each year, but weather influences on MSAL alkaloid production have not been determined. Leaves and reproductive parts may show similar yearly means simply because leaf concentrations are high early in the season, and pod concentrations are high late in the season.

Direct comparisons of alkaloid concentrations in the present study with earlier tall larkspur studies are not pussible because only recently was the MSAL alkaloid fraction determined to be the toxic fraction (Manners et al. 1993). Earlier studies in Utah and Idaho (Pfister et al. 1988a, 1988b, Pfister and Manners 1991) only report total alkaloid concentrations. Nonetheless, in earlier work, we found similar trends in total alkaloid concentrations during the bud and flower stages of growth.

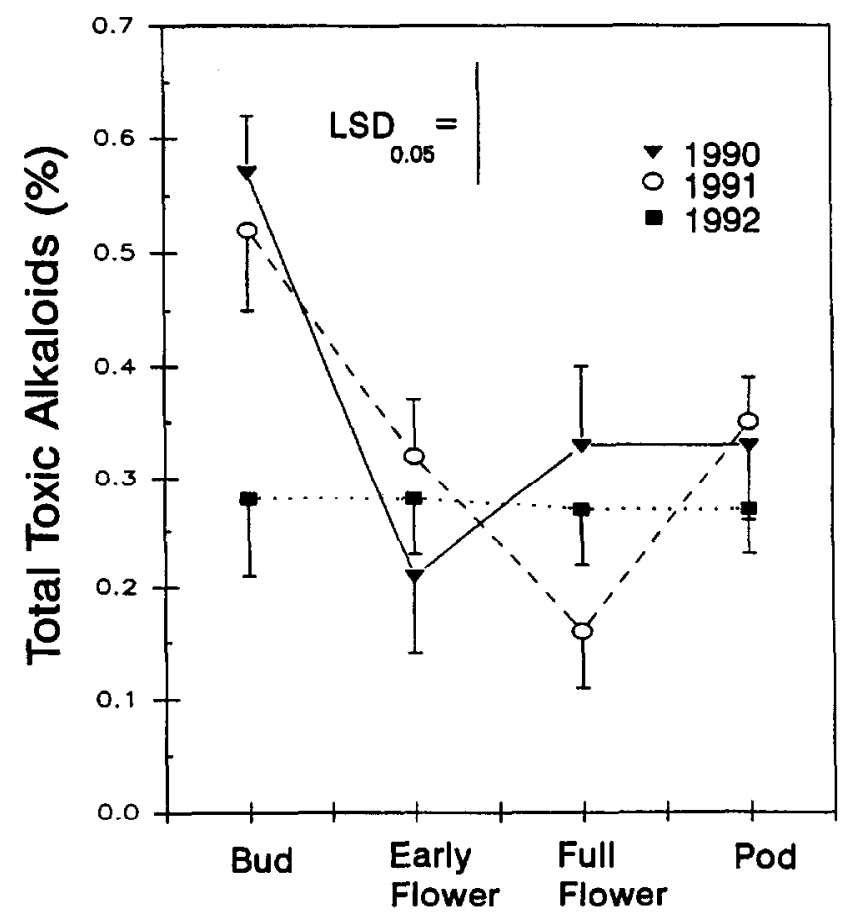

Fig. 1. Concentration (\% of dry weight) of MSAL-type toxic alkaloids in tall larkspur at various phenological stages during 1990 to 1992 near Yampa, Colorado. 


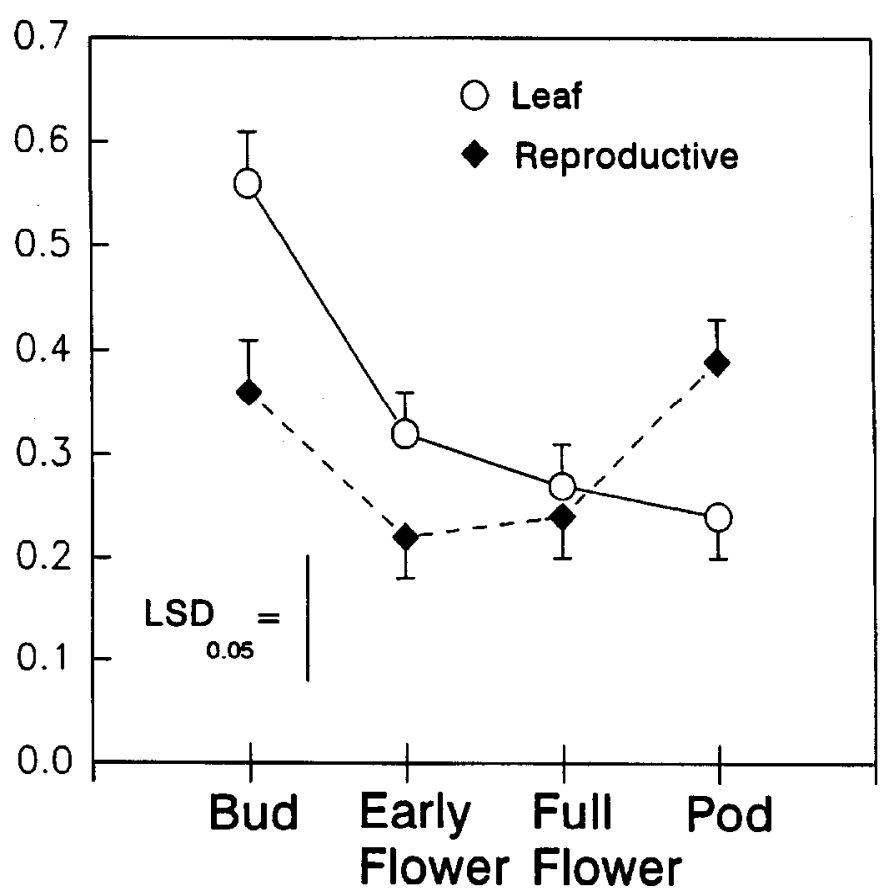

Fig. 2. Concentration ( $\%$ of dry weight) of MSAL-type toxic alkaloids in tall larkspur leaves and reproductive parts at various phenological stages during 1990 to 1992 near Yampa, Colorado.

Contrary to previous work with total alkaloids, we did not find a significant decrease in MSAL alkaloid concentration late in the growing season. The increase in MSAL alkaloid concentrations during late summer, 1991, and the lack of a meaningful decrease in other years, is critical to understand plant toxicity and cattle losses. For example, during August, 1991, 30 head of cattle in a herd of about 180 were fatally poisoned by tall larkspur on this allotment. Toxic MSAL alkaloid concentrations were about $0.4 \%$ in the leaves and $0.5 \%$ in the pods just 5 days before the poisoning episode. Recent toxicity tests indicate that an oral dose of ground tall larkspur equivalent to $11 \mathrm{mg}$ of MSAL alkaloids $/ \mathrm{kg}$ of body weight in cattle causes muscular fatigue and collapse (Pfister et al. 1994a). Assuming an $\mathrm{LD}_{50}$ of about $25 \mathrm{mg} \mathrm{MSAL}$ alkaloids $/ \mathrm{kg}$ of body weight (Pfister et al. 1994a), a $400 \mathrm{~kg}$ grazing cow would consume a toxic dose by eating about $10 \mathrm{~kg}$ of fresh tall

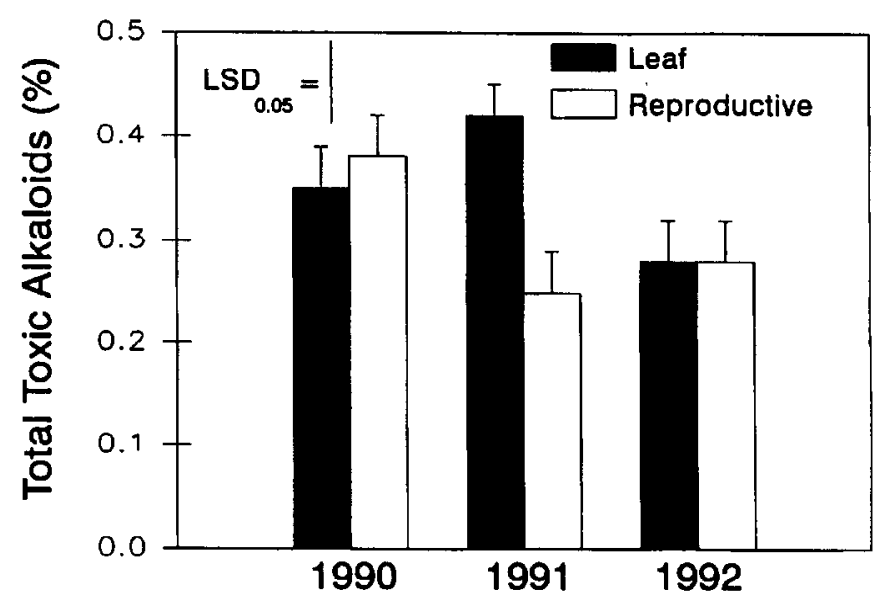

Fig. 3. Concentration ( $\%$ of dry weight) of MSAL-type toxic alkaloids in tall larkspur leaves and reproductive parts during 1990 to 1992 near Yampa, Colorado. larkspur containing $0.5 \%$ MSAL alkaloids. Tall larkspur contains about $20 \%$ dry matter; hence, a fatal dose would be about $2 \mathrm{~kg}$ dry weight. Cattle that survived this episode either ate less tall larkspur, or had a lower rate ( $g$ hour') of tall larkspur consumption (Pfister, unpublished observations).

Nation et al. (1982) reported intravenous (i.v.) injections of purified MLA at about $1.1 \mathrm{mg} / \mathrm{kg}$ of body weight caused muscular collapse in a calf. Our oral estimate of toxicity for total toxic alkaloids is substantially greater than this amount, reflecting differences in route of administration. In general, i.v. injections of tall larkspur alkaloids are considerably more toxic than either subcutaneous injections (Manners et al. 1993) or oral ingestion (Olsen and Sisson 1991).

Concurrent observations of cattle grazing indicated that concentration of MSAL alkaloids has little influence on amounts of tall larkspur consumed. Cattle consumption (Fig. 4) is shown for the day tall larkspur samples were collected. During 1990, cattle ate no tall larkspur. Consumption in 1991 and 1992 tended to increase over time, and to peak in the pod stage, even though MSAL alkaloid concentrations were either static or increasing. The lack of a relationship between MSAL alkaloid concentrations and cattle consumption has been confirmed in numerous pen trials (Pfister, unpublished data).
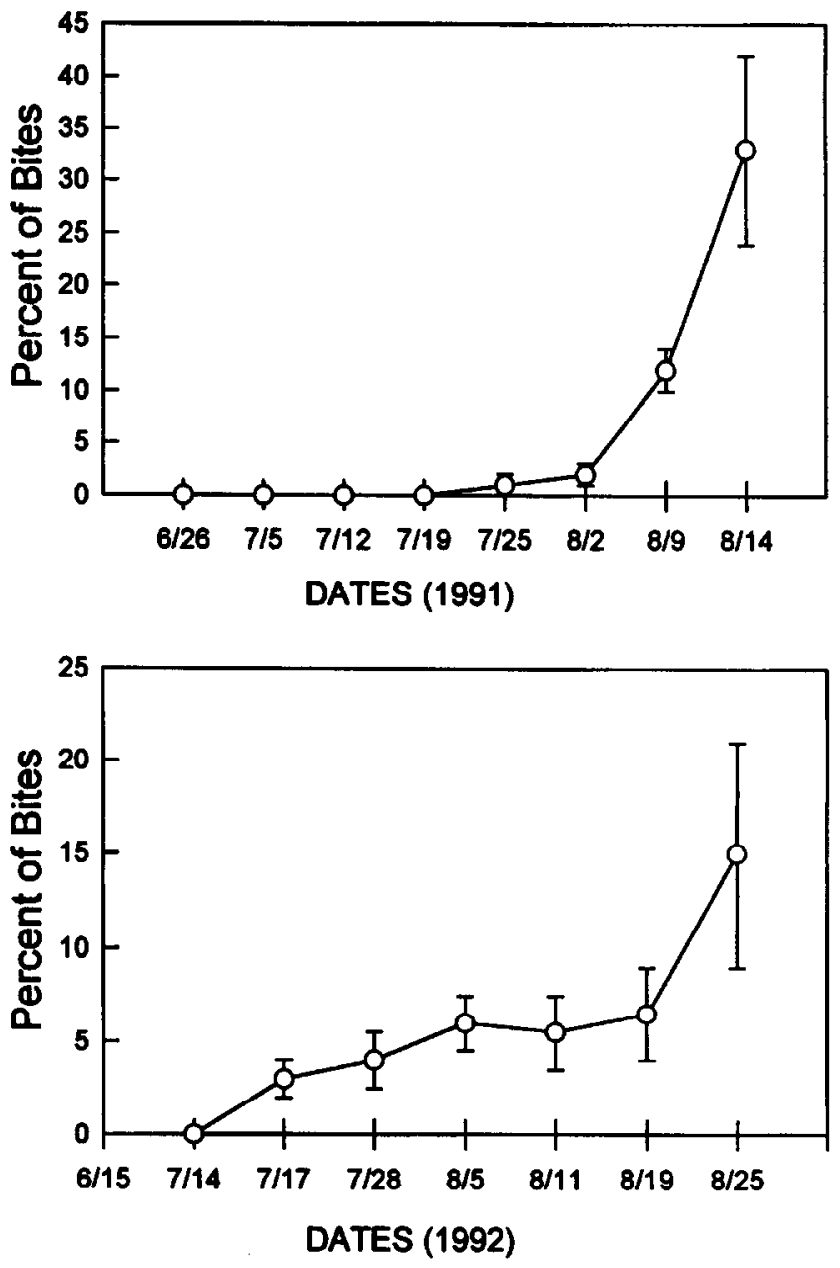

Fig. 4. Cattle consumption of larkspur ( $\%$ of bites) on the day tall larkspur samples were collected for alkaloid analysis during 1991 and 1992 near Yampa, Colorado. Cattle ate no larkspur during 1990. 
Our study suggests that it will be difficult to reduce tall larkspur losses in Colorado simply by deferring cattle grazing until the plant is in the pod stage. Grazing cattle during the pod stage may exacerbate losses during some years if cattle increase tall larkspur consumption and MSAL alkaloid levels increase, or do not decrease, at the end of the growing season. Producers should consider deferment until tall larkspur senesces entirely, as often happens after the first killing frost. Alternatively, livestock producers may consider grazing tall larkspur ranges early in the grazing season until the plant flowers. Even though alkaloid concentrations, and toxicity are high, we have noted cattle rarely consume tall larkspur before flowering in Utah, Idaho, and Colorado (Pfister et al. 1988b, Pfister and Manners 1991, Pfister and Manners 1994). A combination of early- and late- season grazing may increase utilization of tall larkspur-infested ranges without increasing the risk of cattle losses.

\section{Literature Cited}

Gershenzon, J. 1984. Changes in the levels of plant secondary metabolites under water and nutrient stress. pp. 273-321 In: Phytochemical adaptations to stress, Timmerman, B.N. et al. (eds.), Plenum Press, N.Y.

Majak, W. 1993. Alkaloid levels in a species of low larkspur and their stability in rumen fluid. J. Range Manage. 46:100-103.

Manners, G.D., K.E. Panter, M.H. Ralphs, J.A. Pfister, and J.D. Olsen. 1993. The occurrence and toxic evaluation of norditerpenoid alkaloids in the tall larkspurs (Delphinium sp.). J. Agr. Food Chem. 41:96-100.

Manners, G.D., and J.A. Pfister. 1993. Normal phase liquid chromatographic analysis of toxic norditerpenoid alkaloids. Phytochem. Anal. 4:14-18.

Manners, G.D, J.A. Pfister, M.H. Ralphs, K.E. Panter, and J.D. Olsen. 1992. Larkspur chemistry: toxic alkaloids in tall larkspurs. J. Range Manage. 45:63-66.

Mitchell, J.E. 1993. The rangelands of Colorado. Rangelands 15:213-219.
Nation, P.N., M.H. Benn, S.H. Roth, and J.L. Wilkens. 1982. Clinical signs and studies of the site of action of purified larkspur alkaloid, methyllycaconitine, administered parenterally to calves. Can. Vet. J. 23:264-266.

Nielsen, D.B., and M.H. Ralphs. 1988. Larkspur: economic considerations. pp. 119-129 In: The ecology and economic impact of poisonous plants on livestock production, L.F. James et al. (eds.), Westview Press, Boulder, Colo.

NOAA. 1990-1992. National Oceanic and Atmospheric Administration. Climatological data annual summary: Colorado. National Climatic Data Center, Asheville, N.C.

Olsen, J.D., and D.V. Sisson. 1991. Toxicity of extracts of tall larkspur (Delphinium barbeyi) in mice, hamsters, rats and sheep. Tox. Let. 56:33-41.

Pfister, J.A., and G.D. Manners. 1991. Mineral supplementation of cattle grazing larkspur-infested rangeland during drought. J. Range Manage. 44:105-111.

Pfister, J.A., and G.D. Manners. 1994. Effect of carbachol administration in cattle grazing tall larkspur-infested range. J. Range Manage. in review.

Pfister, J.A., G.D. Manners, M.H. Ralphs, Z.X. Hong, and M.A. Lane. 1988a. Effects of phenology, site and rumen fill on tall larkspur consumption by cattle. J. Range Manage. 41:509-514.

Pfister, J.A., K.E. Panter, and G.D. Manners. 1994a. Effective dose in cattle of toxic alkaloids from tall larkspur (Delphinium barbeyi). Vet. Human Toxicol. 36:10-11.

Pfister, J.A., K.E. Panter, G.D. Manners, and C.D. Cheney. 1994b. Reversal of tall larkspur (Delphinium barbeyi) toxicity with physostigmine. Vet. Human Toxicol. (in press)

Pfister, J.A., M.H. Ralphs, and G.D. Manners. 1988b. Cattle grazing tall larkspur on Utah mountain rangelands. J. Range Manage. 41:118-122.

Ralphs, M.H., J.D. Olsen, J.A. Pfister, and G.D. Manners. 1988. Plant-animal interactions in larkspur poisoning in cattle. J. Anim. Sci. 66:23342342.

SAS. 1987. Statistical Analysis System, Ver. 6, Raleigh, N.C. 